\title{
Mesenchymal stem cells differentially mediate regulatory $T$ cells and conventional effector $T$ cells to protect fully allogeneic islet grafts in mice
}

\author{
D. M. Xu $\cdot$ X. F. Yu $\cdot$ D. Zhang $\cdot$ M. X. Zhang $\cdot$ \\ J. F. Zhou $\cdot$ P. H. Tan $\cdot$ Y. C. Ding
}

Received: 9 August 2011 /Accepted: 28 November 2011 /Published online: 20 January 2012

(C) Springer-Verlag 2012

\begin{abstract}
Aims/hypothesis Limited information is available on the cellular interactions between regulatory $\mathrm{T}\left(\mathrm{T}_{\text {reg }}\right)$ cells and mesenchymal stem cells (MSCs). In particular, a direct effect of MSCs on the survival and proliferation of $\mathrm{T}_{\text {reg }}$ cells has not been demonstrated.

Methods We investigated the effects of MSCs on effector T $\left(\mathrm{T}_{\text {eff }}\right)$ cells and $\mathrm{T}_{\text {reg }}$ cells, and the molecular mechanisms involved in the distinct regulation of these two cell populations by MSCs in vivo and in vitro.

Results We show that MSCs are capable of selectively suppressing $\mathrm{T}_{\text {eff }}$ cells and fostering the generation of $\mathrm{T}_{\text {reg }}$ cells. $T_{\text {eff }}$ cells, but not $T_{\text {reg }}$ cells, fail to respond to IL-2 and undergo profound apoptosis in the presence of MSCs. The differential regulations of these two T cell subsets by MSCs are associated with their distinct expressions of CD25, with MSCs specifically reducing the expression of CD25 on $\mathrm{T}_{\text {eff }}$ and sparing $\mathrm{T}_{\text {reg }}$ cells intact. In vivo, the administration of MSCs significantly delays the rejection of allogeneic islet grafts in adaptive transferred recipients by favouring the induction of $\mathrm{T}_{\text {reg }}$ cells. In this model, MSCs inhibit the
\end{abstract}

X. F. Yu • D. Zhang $\cdot$ M. X. Zhang $\cdot$ Y. C. Ding $(\bowtie)$

Department of Endocrinology, Tongji Hospital, Tongji Medical

College, Huazhong University of Science and Technology,

Wuhan, Hubei 430030, People's Republic of China

e-mail: yunchuanding@yahoo.co.uk

D. M. Xu • J. F. Zhou

Department of Haematology, Tongji Hospital, Tongji Medical

College, Huazhong University of Science and Technology,

Wuhan, Hubei, People's Republic of China

P. H. Tan

Nuffield Department of Surgery, University of Oxford,

John Radcliffe Hospital,

Oxford, UK proliferation and development of alloreactive $\mathrm{T}_{\text {eff }}$ but potently enhance the induction of $\mathrm{T}_{\text {reg }}$ cells.

Conclusions/interpretation We demonstrate that MSCs are capable of regulating $T_{\text {eff }}$ and $T_{\text {reg }}$ cells differentially in vitro. MSCs inhibit $T_{\text {eff }}$ cells by inducing apoptosis and impairing the proliferative response to IL-2 in $T_{\text {eff }}$ cells, but favour the survival and expansion of $\mathrm{T}_{\text {reg }}$ cells. This result is further demonstrated in mice that have undergone allogeneic islet transplantation, in which MSCs suppress alloreactive $T_{\text {eff }}$ cells while favouring the induction of $T_{\text {reg }}$ cells, thus protecting the islet allografts from rejection.

Keywords Immunosuppression · Islet transplantation ·

Mesenchymal stem cells

$\begin{array}{ll}\text { Abbreviations } \\ \text { BMFC } & \text { Bone marrow flushed cell } \\ \text { CFSE } & \begin{array}{l}\text { 5,6-Carboxyfluorescein diacetate } \\ \text { succinimidyl ester }\end{array} \\ & \begin{array}{ll}{ }^{3} \mathrm{H}-\mathrm{TdR} & {\left[{ }^{3} \mathrm{H}\right] \text { Thymidine }} \\ \text { FOXP3 } & \text { Forkhead box P3 } \\ \text { MFI } & \text { Mean fluorescent intensity } \\ \text { MSC } & \text { Mesenchymal stem cell } \\ \text { STZ } & \text { Streptozotocin } \\ \mathrm{T}_{\text {eff }} & \text { Effector T cells } \\ \mathrm{T}_{\text {reg }} & \text { Regulatory T cells }\end{array}\end{array}$

\section{Introduction}

Mesenchymal stem cells (MSCs) are a rare subset of cells within the bone marrow cavity with proliferative capacity and an ability to differentiate into a variety of mesodermal tissues [1-3]. The suppressive capabilities of MSCs are 
exploited to control several subsets of immune cells as well as to reduce inflammatory cytokine production $[4,5]$. MSCs have been shown to inhibit effector $\mathrm{T}$ ( $\mathrm{T}_{\text {eff }}$ ) lymphocyte proliferation induced by alloantigens or mitogens $[4,6,7]$. Recently, we showed that MSCs exert potent immunosuppressive properties by reducing the surface expression of $\mathrm{CD} 25$, the alpha subunit of the IL-2 receptor, on $\mathrm{T}_{\text {eff }}$ cells, thus blocking the IL-2 cytokine signalling pathway required for $\mathrm{T}$ lymphocyte activation, expansion and differentiation [8]. By targetting the detrimental alloreactive $\mathrm{T}$ cell response, MSCs have been shown to exhibit therapeutic potential in controlling or preventing graft rejection in many experimental animal models of organ transplantation [9-11].

$\mathrm{CD} 25^{+} \mathrm{CD} 4^{+}$regulatory $\mathrm{T}$ cells $\left(\mathrm{T}_{\text {reg }}\right)$, which account for $5-10 \%$ of CD4 T cells, are an important cellular subset with immunosuppressive activity that have been demonstrated to suppress immune responses directed against allografts as well as against pathogen antigens in mice and humans [12, 13]. Rather than being subjected to MSC-mediated immunosuppression like their $\mathrm{CD} 4^{+} \mathrm{CD} 25^{-} \mathrm{T}_{\text {eff }}$ counterparts, it has been reported that $\mathrm{T}_{\text {reg }}$ cells can be induced by MSCs in vitro and in patients following autologous MSC therapy [14-16]. However, the precise mechanisms mediating such differential effects remain elusive. This is an important question that needs to be addressed in order to develop MSC-based immunotherapy that allows a selective targetting of alloreactive $T_{\text {eff }}$ cells while sparing $T_{\text {reg }}$ cells with regulatory activities.

Islet transplantation offers an attractive and effective approach to the treatment of patients with type 1 diabetes, and can lead to a normal metabolic control of glucose levels and an independence from exogenous insulin [17]. Despite great success in terms of restoring normoglycaemia, the long-term efficacy of this approach after transplantation has been limited due to chronic graft rejection [18]. Immunosuppressive regimens used in the Edmonton protocol and its derivatives [17, 19], such as tacrolimus, have been found to affect the calcineurin-dependent IL-2 production that is critical for $T_{\text {reg }}$ function and expansion in preventing graft rejection [20]. Thus, an optimal approach would involve an improved islet transplantation protocol that would prevent graft rejection without the need for potentially dangerous long-term and non-specific immune suppression. Previous reports [21], including our own results [8], have shown that the infusion of MSCs results in a reversal of rejection episodes and a prolongation of islet function in islet-transplanted animal models, cementing the rationale for the therapeutic application of MSCs in allogeneic islet transplantation. The precise mechanisms involved in the beneficial effects of MSCs in allogeneic islet transplantation, however, require further investigation.

In this study, we demonstrate the differential regulation by MSCs of $T_{\text {eff }}$ and $T_{\text {reg }}$ cells with regard to their differences in expansion, survival and response to IL-2. Our results show that MSCs are capable of fostering the survival and expansion of $\mathrm{T}_{\text {reg }}$ cells while inducing potent apoptosis and an impaired proliferative response to IL-2 in $\mathrm{T}_{\text {eff }}$ cells. To explore the functionality of MSCs with regulatory activity in vivo, we used a mouse islet allograft transplantation model with BALB/c $\mathrm{Rag}^{-1-} \gamma^{-/-}$mice, deficient in T, B and natural killer cells, as recipients. Using these, we analysed the rejection response against MHC fully mismatched C57BL/6 islet allografts and assessed the impact of MSCs with regulatory activity on the modulation of this response in vivo.

\section{Methods}

Mice C57BL/6 (B6, H2b), BALB/c (H2d), and BALB/c $\mathrm{Rag}^{-/-} \gamma^{-/-}$mice were originally purchased from the Jackson Laboratory (Bar Harbor, ME, USA). The mice were bred and housed under specific pathogen-free conditions at the Tongji Medical School Facilities for Animal Care and Housing, and were between 6 and 8 weeks of age at the time of the first procedure. All animal studies were carried out according to the guidelines of the Chinese Council on Animal Care and were approved by the Tongji Medical College Committees on Animal Experimentation.

MSCs Bone marrow cells were collected from the femurs and tibias of BALB/c mice by a standard flushing method, and cultured according to the protocol previously described [8]. The identification of all primary MSCs was confirmed by morphology, phenotypic analysis and their capability to differentiate into adipocytes and osteoblasts under appropriate culture conditions, as previously described [8]. All experiments were set up within passage 10 of the MSC cultures.

Selection of $C D 4^{+} C D 25^{-} T$ cells $\mathrm{CD} 4^{+} \mathrm{CD} 25^{-} \mathrm{T}_{\text {eff }}$ and $\mathrm{CD} 4^{+} \mathrm{CD} 25^{+} \mathrm{T}_{\text {reg }}$ cells were purified from the spleen of BALB/c mice using CD25 MicroBeads (Miltenyi Biotech, Bergisch Gladbach, Germany). Each preparation used in this study was greater than $95 \%$ pure by FACS analysis.

Proliferation assay Standard 3-day cultures were set up in 96-well round-bottomed plates using $1 \times 10^{5} \mathrm{~T}_{\text {eff }}$ or $\mathrm{T}_{\text {reg }}$ cells stimulated by CD3/CD28 Dynabeads (Invitrogen, Carlsbad, CA, USA) in a 1:1 ratio with the number of $\mathrm{T}$ cells in the presence of $2 \times 10^{4}$ MSCs. Thymidine was added during the last $18 \mathrm{~h}$ of culture before measuring the incorporation of $\left[{ }^{3} \mathrm{H}\right]$ thymidine $\left({ }^{3} \mathrm{H}-\mathrm{TdR}\right)$ using a liquid scintillation counter.

Flow cytometry Single-cell suspensions were generated from spleen and lymph nodes, and red cell lysis was performed by brief exposure to deionised water. Aliquots were then divided for various panels of analysis. $T_{\text {reg }}$ cells were 
identified by co-expression of CD4 and CD25, and intracellular detection of forkhead box P3 (FOXP3). For cytokine analysis, cells were re-stimulated for $5 \mathrm{~h}$ with PMA (SigmaAldrich, St Louis, MO, USA) before being stained for intracellular IFN- $\gamma$, IL-10, IL-4 and TGF- $\beta$ (BD Biosciences, San Diego, CA, USA).

Induction of diabetes BALB/c $\operatorname{Rag}^{-/-} \gamma^{-/-}$mice were rendered diabetic by a single intravenous injection of $200 \mathrm{mg} / \mathrm{kg}$

a
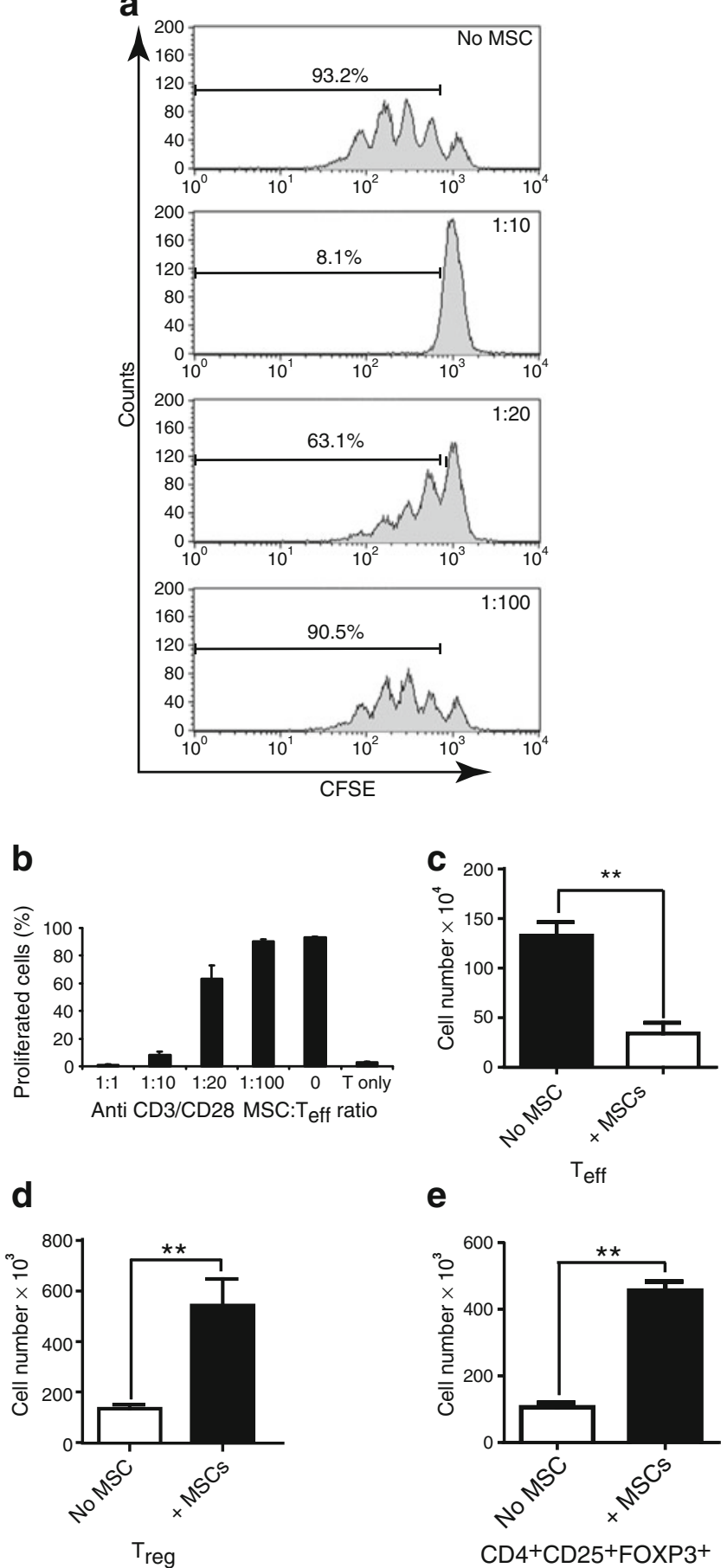

e

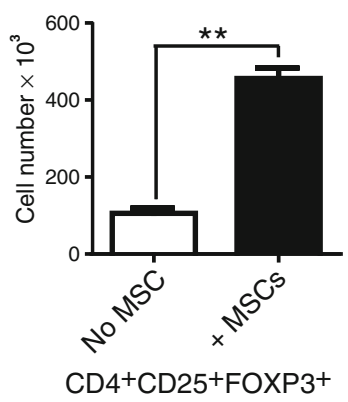

streptozotocin (STZ; Sigma-Aldrich). The dose of STZ was titrated to give a level of about $20 \mathrm{mmol} / \mathrm{l}$ blood glucose at the day of islet transplantation.

Islet isolation Islets were isolated from mouse pancreata (C57BL/6) by a discontinuous Ficoll gradient centrifugation as previously described [8], and were counted under a microscope after dithizone staining.

Adoptive transfer of cells and islet transplantation A total

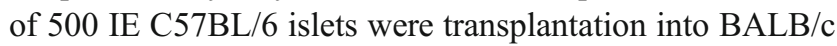
$\mathrm{Rag}^{-1-} \gamma^{-1-}$ mice. Islets were aggregated in a clot of recipient $(\mathrm{BALB} / \mathrm{c})$ strain blood, and inserted into a subcapsular pocket of the left kidney. The grafts were allowed to normalise for 2 days before the adoptive transfer of allogeneic splenocytes. $\mathrm{BALB} / \mathrm{c} \mathrm{Rag}^{-1-} \gamma^{-1-}$ mice were reconstituted intraperitoneally with $1 \times 10^{6}$ splenocytes from naive BALB/c mice, or with $3 \times$ $10^{6} \mathrm{BALB} / \mathrm{c}$ MSCs or bone marrow flushed cells (BMFCs). Blood glucose levels were determined using a blood glucose meter (Accu-Chek Advantage Meter; Roche Diagnostics, Basel, Switzerland). Rejection was defined as a blood glucose level of more than $14.5 \mathrm{mmol} / \mathrm{l}$ for at least two consecutive days. In same experiments, graft function was determined by removing the kidney containing the transplanted islets.

Immunofluorescence To visualise the functional islets transplanted beneath the kidney capsule, kidneys were frozen in Tissue-Tek OCT compound (Sakura Finetek, Torrance, CA), and $10 \mu \mathrm{m}$ sections were stained for insulin according to the protocols previously described [8]. Nuclear counterstaining was performed using Hoechst dye, and sections were viewed with a Leica epifluorescence microscope (Leica Microsystems, Wetzlar, Germany).

Fig. 1 a,b A total of $2 \times 10^{5} \mathrm{CD} 4^{+} \mathrm{CD} 25^{-} \mathrm{T}_{\text {eff }}$ cells from naive BALB/c (H2d) mice were stimulated by anti-CD3/CD28 Dynabeads in a $1: 1$ bead:cell ratio alone (no MSCs) or in the presence of a graded number of MSCs in each well of a 96-well plate for $72 \mathrm{~h}$. CFSE fluorescence intensities were analysed by flow cytometry. The percentage of cells proliferating was calculated by dividing the number of cells undergoing division by the total number of $\mathrm{T}$ cells present in the culture. Standard 3-day cultures were set up in 96-well round-bottomed plates using $1 \times 10^{5} \mathrm{CD} 4^{+} \mathrm{CD} 25^{-} \mathrm{T}_{\text {eff }}$ cells (c) or $\mathrm{CD} 4^{+} \mathrm{CD} 25^{+} \mathrm{T}_{\text {reg }}$ cells (d) stimulated by $\mathrm{CD} 3 / \mathrm{CD} 28$ Dynabeads in a 1:1 bead:cell ratio in the presence of $2 \times 10^{4} \mathrm{BALB} / \mathrm{c}$ MSCs. To obtain cell counts, a fixed number of Calibrite beads were added to the cells, and the ratio of 7-amino-actinomycin D (7-AAD) ${ }^{-} \mathrm{T}$ cells to beads was determined by flow cytometry. Absolute numbers of viable $\mathrm{T}$ cells were calculated by multiplying this ratio by the absolute number of beads added to the cells. e The numbers of $\mathrm{CD} 4^{+} \mathrm{CD} 25^{+} \mathrm{FOXP} 3^{+}$cells were obtained by multiplying the percentage of these cells by the number of Calibrite beads added to the cultures prior to acquisition. Data are represented as mean $\pm \mathrm{SD} .{ }^{* *} p<0.01, \mathrm{~T}_{\text {reg }}$ cells co-cultured with MSCs (+MSCs) vs $\mathrm{T}_{\text {reg }}$ cells cultured alone (no MSC). Results are the average of at least three experiments of identical design 
Statistical analysis Data are expressed as mean \pm SE. Kaplan-Meier analysis was used for survival analysis with significance set at $p<0.05$. The Student's $t$ test was used for two-tailed comparison.

\section{Results}

MSCs suppress the proliferation of $T_{\text {eff }}$ but not $T_{\text {reg }}$ cells MSCs obtained from BALB/c bone marrow cells are spindle-shaped, with a typical MSC phenotype-positive for CD44, CD73, CD105, and negative for CD11b - distinct from that of fibroblasts (data not shown). Under the appropriate culture conditions, the MSCs can be differentiated into adipogenic and osteogenic lineages, as verified by oil red $\mathrm{O}$ and Alizarin red staining (for adipogenic and osteogenic induction) [8].

In order to examine the effect of MSCs on $\mathrm{T}_{\text {eff }}$ responses in vitro, $T_{\text {eff }}$ cells were stimulated with anti-CD3/CD28 beads with or without a graded number of MSCs. As shown in Fig. 1a,b, $T_{\text {eff }}$ cells proliferated vigorously in response to anti-CD3/CD28 stimulation, and $93.2 \%$ of $\mathrm{T}_{\text {eff }}$ cells lost 5,6carboxyfluorescein diacetate succinimidyl ester (CFSE) fluorescence intensity; however, MSCs profoundly prevented $\mathrm{T}_{\text {eff }}$ proliferation in a dose-dependent manner, resulting in a potent inhibition of cell proliferation at a ratio of 1:10 or 1:20 (MSC : T cell) respectively.

To compare the regulatory effects of MSCs on the $\mathrm{T}_{\text {eff }}$ and $\mathrm{T}_{\text {reg }}$ populations, $\mathrm{CD} 4^{+} \mathrm{CD} 25^{-} \mathrm{T}_{\text {eff }}$ and $\mathrm{CD} 4^{+} \mathrm{CD} 25^{+}$ naive $\mathrm{T}_{\text {reg }}$ cells were isolated from single-cell suspensions of splenocytes, and were stimulated with anti-CD3/CD28 beads alone or in the presence of MSCs. Absolute cell numbers were quantified by flow cytometry after adding Calibrite beads (BD Biosciences) to the cultures. As shown in Fig. 1c, the presence of MSCs resulted in a significant reduction of the $\mathrm{T}_{\text {eff }}$ population. Interestingly, in a converse regulatory fashion, MSCs induced the expansion of $T_{\text {reg }}$ cells, as demonstrated by a fourfold increase in the number a
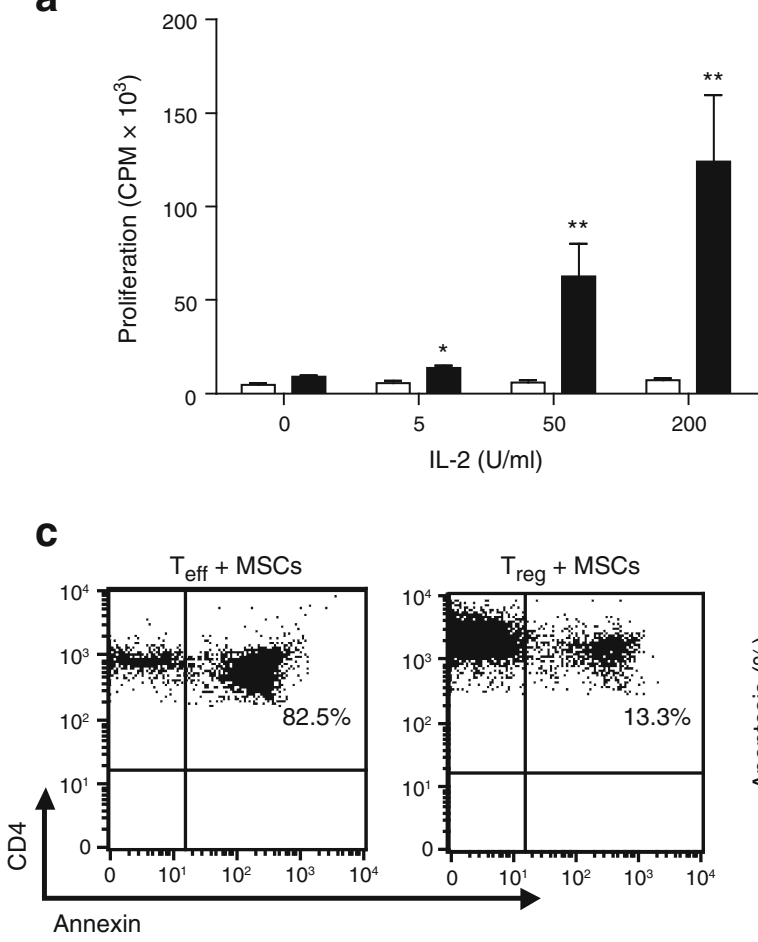

b

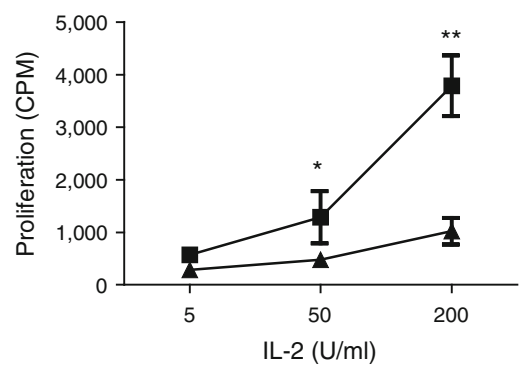

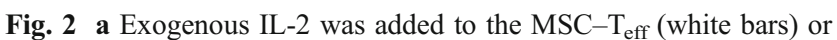
MSC- $\mathrm{T}_{\text {reg }}$ (black bars) co-cultures at concentrations of 5, 50 and $200 \mathrm{IU} / \mathrm{ml}$. After $72 \mathrm{~h}$, cell proliferation was measured from the incorporation of ${ }^{3} \mathrm{H}-\mathrm{TdR}$ added during the last $8 \mathrm{~h}$ of culture. Data are represented as mean $\pm \mathrm{SD}$. Results are the average of three experiments of identical design. b CD $4^{+} \mathrm{CD} 25^{-} \mathrm{T}_{\text {eff }}$ (squares) or $\mathrm{CD} 4^{+} \mathrm{CD} 25^{+}$ $\mathrm{T}_{\text {reg }}$ (triangles) cells from naive $\mathrm{BALB} / \mathrm{c}$ mice were stimulated with anti-CD3/CD28 beads in the presence of MSCs (MSC:T cell ratio 1:5) for $72 \mathrm{~h}$. T cells were purified by anti-CD4 magnetic beads (Miltenyi Biotech) and cultured with 5, 50 and $200 \mathrm{IU} / \mathrm{ml} \mathrm{IL-2}$ for $72 \mathrm{~h}$. Cell

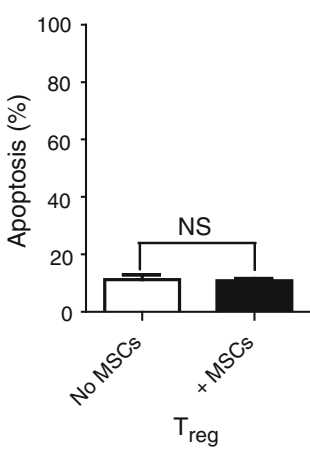

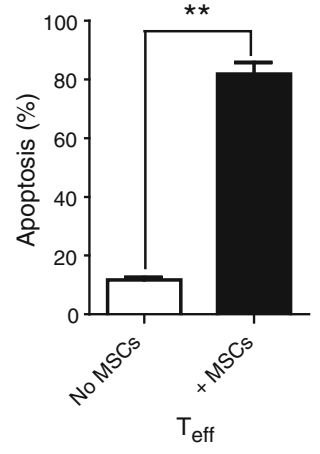

proliferation was analysed by ${ }^{3} \mathrm{H}-\mathrm{TdR}$ incorporation. Data from three independent experiments, each performed in triplicate, are presented as mean $\pm \mathrm{SD}$. CPM, counts per minute. c $\mathrm{CD} 4^{+} \mathrm{CD} 25^{-} \mathrm{T}_{\text {eff }}$ and $\mathrm{CD} 4^{+} \mathrm{CD} 25^{+} \mathrm{T}_{\text {reg }}$ cells were cultured at a density of $1 \times 10^{5}$ per well in 96-well plates, and stimulated with anti-CD3/CD28 beads alone or in the presence of MSCs $\left(2 \times 10^{4}\right)$. Annexin $\mathrm{V}$ staining of $\mathrm{T}_{\text {eff }}$ and $\mathrm{T}_{\text {reg }}$ cells after $72 \mathrm{~h}$ of culture was analysed by flow cytometry. $* * p<0.01$, $\mathrm{NS}=p>0.05$. The data are mean percentage $\pm \mathrm{SD}$ of Annexin Vpositive cells from three individual experiments 
of $\mathrm{T}_{\text {reg }}$ cells co-cultured with MSCs compared with $\mathrm{T}_{\text {reg }}$ cells cultured alone $\left(5.44 \pm 1.80 \times 10^{5}\right.$ vs $1.34 \pm 0.29 \times 10^{5}, p<0.01$; Fig. 1d). The expanded cell populations induced by MSCs were defined as dominantly cells of the $\mathrm{CD} 4^{+} \mathrm{CD} 25^{+} \mathrm{FOXP} 3^{+}$ $\mathrm{T}_{\text {reg }}$ compartment ( $p<0.01$; Fig. 1e).
MSCs differentially regulate the survival and IL-2 response of $T_{\text {eff }}$ and $T_{\text {reg }}$ cells The addition of exogenous IL-2 has already been shown to restore $\mathrm{T}$ cell proliferation in many situations of in vitro cell hyporesponsiveness [22]. We examined the IL-2-driven proliferation of $T_{\text {eff }}$ or $T_{\text {reg }}$ cells

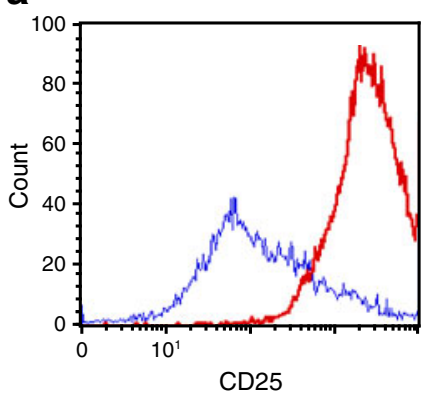

d

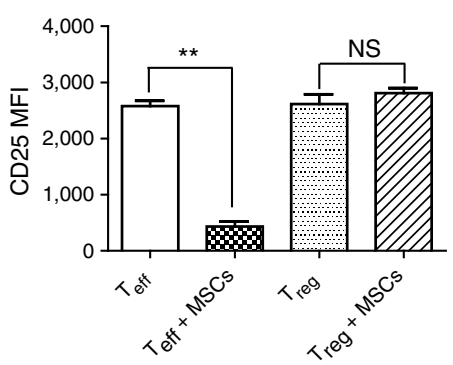

b

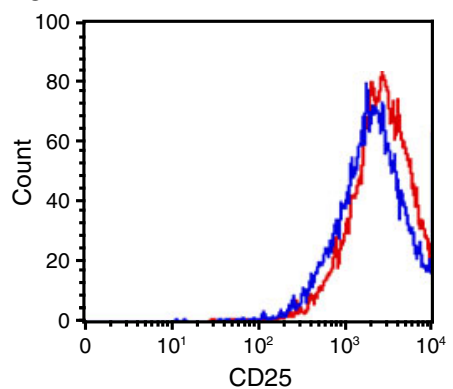

e

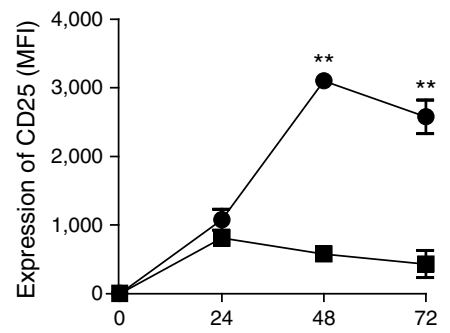

C

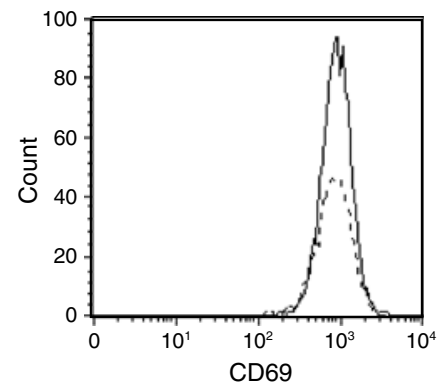

f

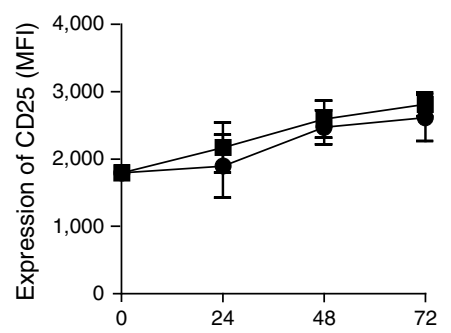

g
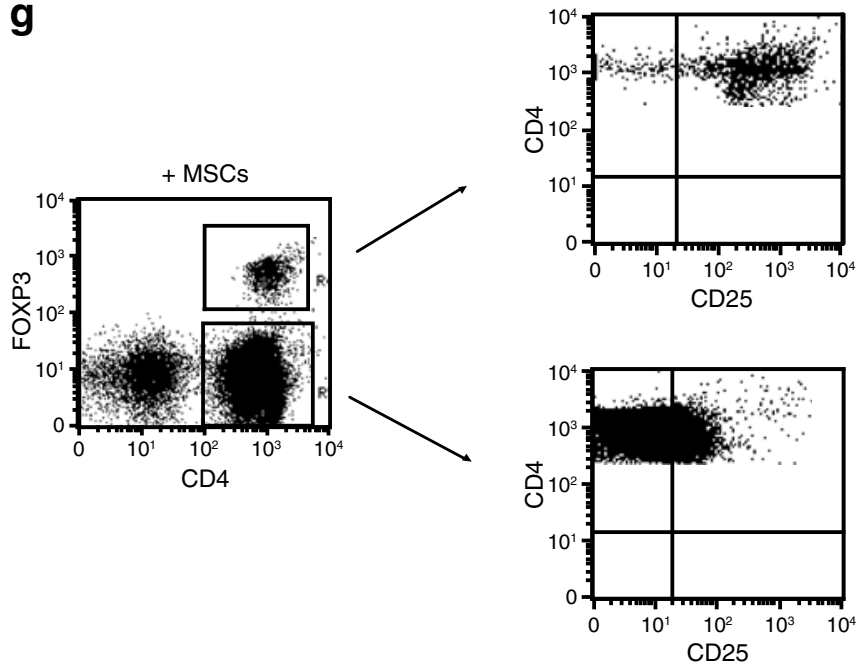

Fig. 3 a-g CD $4^{+} \mathrm{CD} 25^{-} \mathrm{T}_{\text {eff }}$ and $\mathrm{CD} 4+\mathrm{CD} 25^{+} \mathrm{T}_{\text {reg }}$ cells purified from naive $\mathrm{BACL} / \mathrm{c}$ mouse spleens using $\mathrm{CD} 25$ MicroBeads were stimulated with anti-CD3/CD28 beads for $72 \mathrm{~h}$ in the presence (blue line in $\mathbf{a}$ and $\mathbf{b}$ ) or absence (red line in $\mathbf{a}$ and $\mathbf{b}$ ) of MSCs. $\mathbf{c}$ Solid line, $\mathrm{T}_{\text {reg }}+\mathrm{MSCs}$; dotted line, $\mathrm{T}_{\text {eff }}+\mathrm{MSCs}$. Histograms are representative of three independent experiments. $\mathrm{CD} 4^{+} \mathrm{CD} 25^{-} \mathrm{T}_{\text {eff }}(\mathbf{e}$; circles) or $\mathrm{CD} 4{ }^{+} \mathrm{CD} 25^{+} \mathrm{T}_{\text {reg }}$ (f; circles) cells were stimulated with anti-CD3/ CD28 beads and co-cultured with MSCs (squares) for 24,48 and $72 \mathrm{~h}$, followed by surface staining for CD25. ${ }^{* *} p<0.01, \mathrm{~T}_{\text {eff }}$ cells co- cultured with MSCs $\left(\mathrm{T}_{\text {eff }}+\mathrm{MSCs}\right)$ vs $\mathrm{T}_{\text {reg }}$ cells cultured alone $\left(\mathrm{T}_{\mathrm{ef}}\right)$. Data from at least three independent experiments are presented as mean \pm SD. $g$ A total of $1 \times 10^{5}$ T cells (BALB/c) were stimulated with anti-CD3/CD28 in a bead:T cell ratio of 1:1 in the presence of MSCs $\left(2 \times 10^{4}\right)$ for $72 \mathrm{~h}$, followed by surface staining for CD4 and CD25, and intracellular staining for FOXP3. Cells were gated on 7-aminoactinomycin D (7-AAD) ${ }^{-}$lymphocytes, and are represented as mean percentage \pm SD from three independent experiments 
when co-cultured with MSCs. As shown in Fig. 2a, $\mathrm{T}_{\text {eff }}$ cells in the presence of MSCs failed to respond to IL-2, and the proliferation of these cells could not be restored by the addition of exogenous IL-2. In contrast, $\mathrm{T}_{\text {reg }}$ cells in the presence of MSCs responded normally and proliferated in correlation with the amounts of IL-2 added into the cell cultures ( $p<0.01$; Fig. 2a).
We then considered whether the differential response to IL-2 of the $T_{\text {eff }}$ and $T_{\text {reg }}$ cells would remain after the MSCs had been removed. $T_{\text {reg }}$ or $T_{\text {eff }}$ cells co-cultured with MSCs in the primary cultures were re-isolated by positive selection and then incubated with exogenous IL-2 at different concentrations for another $72 \mathrm{~h}$. As shown in Fig. $2 \mathrm{~b}, \mathrm{~T}_{\text {eff }}$ cells stimulated with anti-CD3/CD28 in the primary cultures with a

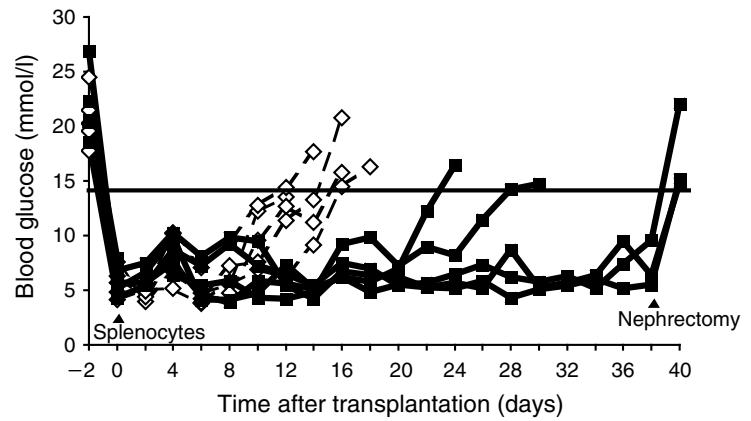

C
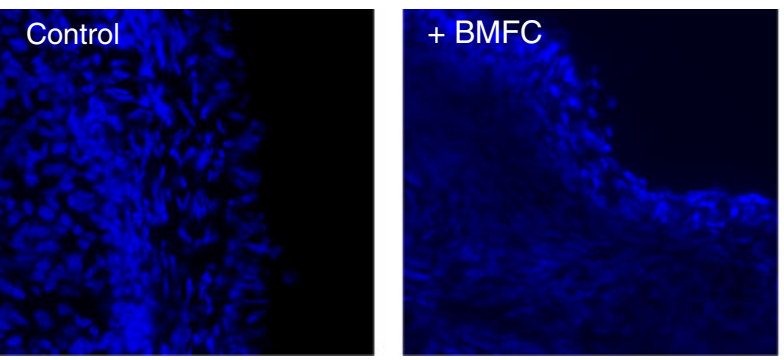

d
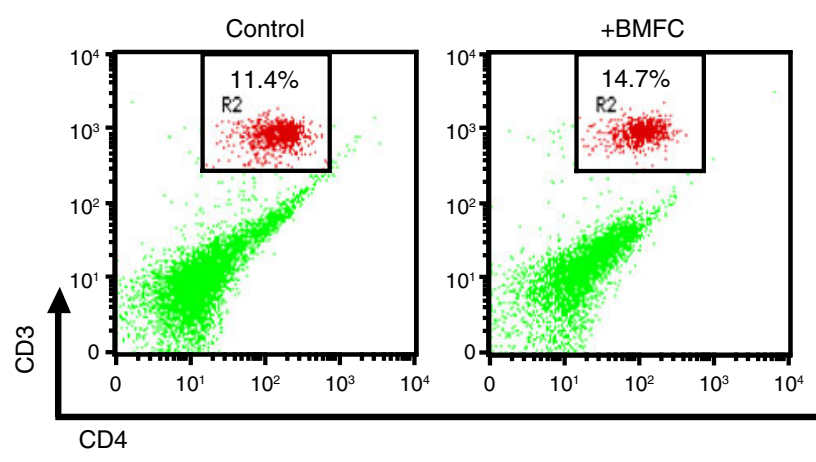

e

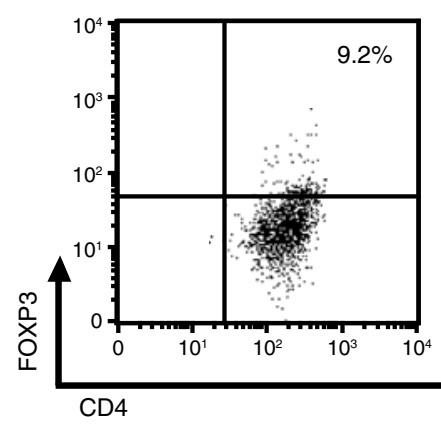

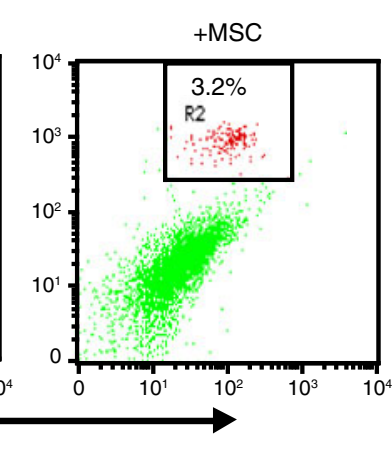

b
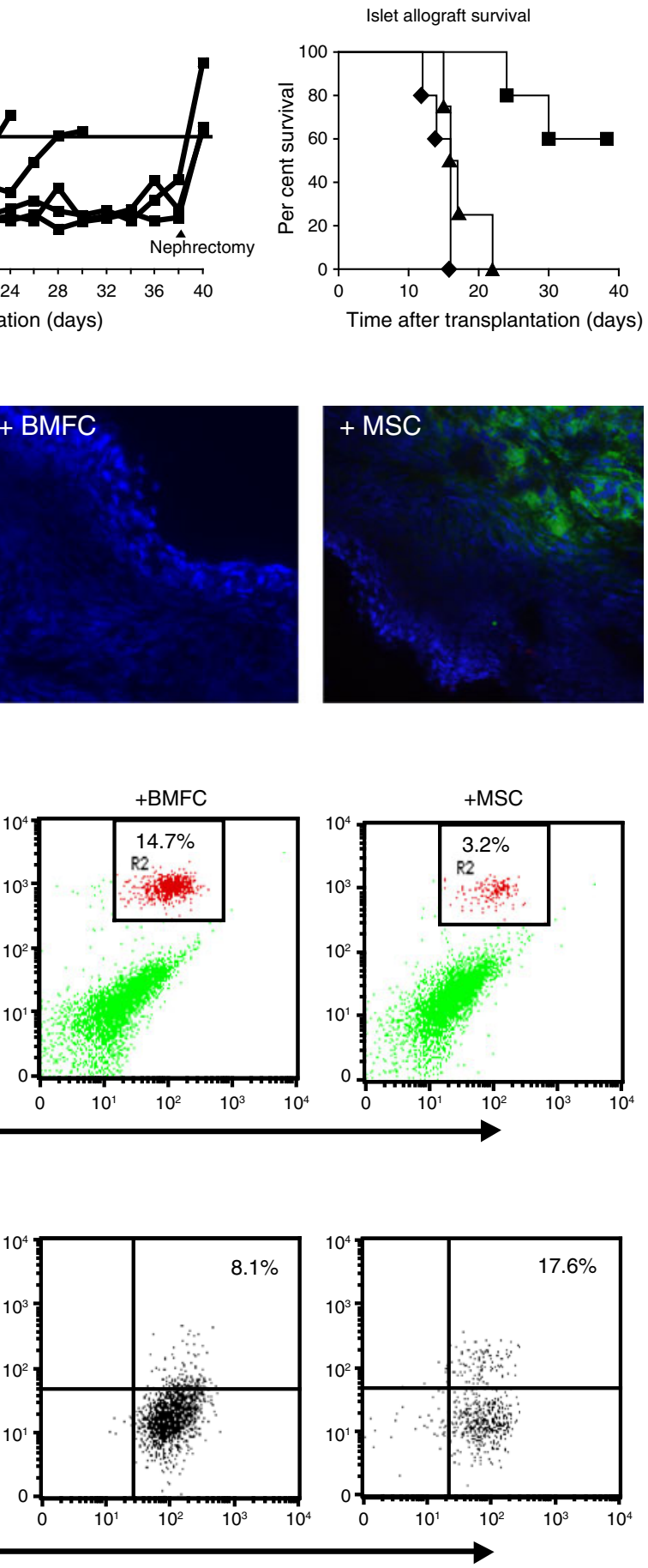
Fig. 4 a BALB/c $\operatorname{Rag}^{-/-} \gamma^{-/-}$mice were rendered diabetic by a single intravenous injection of $200 \mathrm{mg} / \mathrm{kg} \mathrm{STZ}$. Mice had an average blood glucose concentration of $20 \mathrm{mmol} / 1$ immediately prior to islet transplantation. Pancreatic islets (500 islet equivalents, IE) from C57BL/6 mice (H2b) were transplanted under the kidney capsules of STZinduced diabetic BALB/c $\operatorname{Rag}^{-/-} \gamma^{-/-}$mice. The grafts were allowed to normalise for 2 days before the adoptive transfer of allogeneic splenocytes. Islet transplant recipients were reconstituted intraperitoneally with only $1 \times 10^{6}$ naive BALB/c splenocytes as effector populations, or with these together with $3 \times 10^{6} \mathrm{BALB} / \mathrm{c}$ MSC or BMFCs. Rejection was defined as a blood glucose level greater than $14.5 \mathrm{mmol} /$ 1 for at least two consecutive days. Continued function of the islet allografts was confirmed by removal of the islet-bearing kidneys and a return to hyperglycaemia. Square, $+\mathrm{MSC}$; diamond, control. b Islet allograft survival. Square, $+\mathrm{MSC}$; diamond, control; triangle, +BMFC. c Kidneys transplanted with islet grafts were excised at the time of rejection or at the endpoint of this study. Immunofluorescence examination of islet grafts in MSC-treated recipients revealed an intense staining of insulin-producing islets beneath the kidney capsule (c; +MSCs), whereas in the BMFC-treated (BALB/c, +BMFC) and control (control) recipients, the insulin-positive islet tissue was not detected at the time of rejection. d,e At 7 days post-transplantation, the area of kidney containing the islet grafts was dissected. After haemolysis, a single-cell suspension of the islet graft was stained for CD3, CD4 and FOXP3. Cells were gated on a lymphocyte fraction for flow cytometric analysis. Data shown are representative of one individual experiment with $n=3$ for each group

MSCs responded poorly to exogenous IL-2. Intriguingly, $\mathrm{T}_{\text {reg }}$ cells co-cultured initially with MSCs proliferated vigorously in response to IL-2 in secondary cultures.

To determine whether the different responses to IL-2 of the $T_{\text {reg }}$ and $T_{\text {eff }}$ cells were related to the alteration in cell survival, we analysed the apoptosis of these two $\mathrm{T}$ cell subsets when co-cultured with MSCs. As shown in Fig. 2c, the presence of MSCs led to substantial apoptosis of the $\mathrm{T}_{\text {eff }}$ cells: $81.8 \%$ of $\mathrm{T}_{\text {eff }}$ cells co-cultured with MSCs were apoptotic, in clear contrast to a background level of apoptosis in $\mathrm{T}_{\text {eff }}$ cells alone. Intriguingly, the addition of MSCs led to no statistical difference in $\mathrm{T}_{\text {reg }}$ apoptosis (NS, $p>$ $0.05)$, and $\mathrm{T}_{\text {reg }}$ cells did not undergo apoptosis as $\mathrm{T}_{\text {eff }}$ cells did in response to MSC treatment $(10.8 \pm 1.4 \%$ vs $81.8 \pm 6.9 \%, p<$ 0.01 ; Fig. 2c). Taken together, these results demonstrate that MSCs mediated a selective inhibition of $\mathrm{T}_{\mathrm{eff}}$ cells by inducing apoptosis and preventing their proliferation in response to IL-2, but failed to affect the survival and proliferation of the $\mathrm{T}_{\text {reg }}$ cells.

$T_{\text {eff, but not }} T_{\text {reg, }}$, cells lose surface expression of CD25 in the presence of MSCs We and other groups have previously demonstrated that the MSC-mediated suppression of T cell proliferation is related to a significant reduction in CD25 expression on the activated T cells $[8,23,24]$. CD25, known as the alpha subunit of the IL-2 receptor, is constitutively expressed on the surface of $\mathrm{T}_{\text {reg }}$ cells and plays an important role in the survival and expansion of these cell populations [25-27]. We therefore sought to determine whether the different response to IL-2 of $\mathrm{T}_{\text {eff }}$ and $\mathrm{T}_{\text {reg }}$ cells induced by
MSCs was related to the expression of CD25 on these two T cell subsets.

$\mathrm{T}_{\text {eff }}$ and $\mathrm{T}_{\text {reg }}$ cells were stimulated with anti-CD3/CD28 beads (in a cell:bead ratio of 1:1) alone or co-cultured with MSCs for $72 \mathrm{~h}$, and the expression of CD25 was evaluated by flow cytometry. As shown in Fig. 3a, the presence of MSCs led to a substantial reduction in CD25 expression on activated $\mathrm{T}_{\text {eff }}$ cells. CD25 expression (measured as mean fluorescent intensity $[\mathrm{MFI}]$ ) of the $\mathrm{T}_{\text {eff }}$ cells was reduced from $2577 \pm 244 \times 10^{3}$ to $432 \pm 198 \times 10^{3}$ after the addition of MSCs $\left(\mathrm{T}_{\text {eff }}\right.$ vs $\mathrm{T}_{\text {eff }}+\mathrm{MSCs}, \mathrm{p}<0.01$; Fig. 3d). In contrast, MSCs barely affected the expression of CD25 on the $T_{\text {reg }}$ cells. Bead-activated $\mathrm{T}_{\text {reg }}$ cells co-cultured with MSCs expressed CD25 to a similar extent as they did in the absence of MSCs $\left(2614 \pm 346\right.$ of $\mathrm{T}_{\text {reg }}$ vs $2812 \pm 174$ of $\mathrm{T}_{\text {reg }}$ + MSCs, N.S p>0.05; Fig. 3b, d). This different regulation of $\mathrm{T}_{\text {eff }}$ and $\mathrm{T}_{\text {reg }}$ cells by MSCs appeared to be specific to CD25 as the expression of CD69, another activation marker, was unaffected on $T_{\text {eff }}$ cells compared with $T_{\text {reg }}$ cells after co-culture (Fig. 3c).

We then examined the dynamic expression of CD25 on $\mathrm{T}_{\text {eff }}$ and $\mathrm{T}_{\text {reg }}$ cells when co-cultured with MSCs for 24, 48 and $72 \mathrm{~h}$. Our results showed that, although the presence of MSCs had no effect on $\mathrm{T}_{\text {reg }}$ cells, the addition of MSCs resulted in a significant reduction in CD25 expression by $\mathrm{T}_{\text {eff }}$ after 2 days $(p<0.01$, Fig. 3e, f), suggesting the differential regulation by MSCs of the surface expression of CD25 in $T_{\text {eff }}$ and $T_{\text {reg }}$ cells. Additional evidence for this differential regulation is that the presence of MSCs resulted in a statistically significant reduction of CD25 expression only on $\mathrm{CD}^{+} \mathrm{CD} 25^{+} \mathrm{FOXP} 3^{-} \mathrm{T}_{\text {eff }}$ cells, whereas there was no effect on $\mathrm{CD}^{+} \mathrm{CD} 25^{+} \mathrm{FOXP} 3^{+} \mathrm{T}_{\text {reg }}$ cells when the total population of $\mathrm{T}$ cells containing both $\mathrm{T}$ cell compartments was stimulated with anti-CD3/CD28 beads in culture (Fig. 3g). Thus, these results indicate that MSCs specifically modulated the expression of CD25 on $\mathrm{T}_{\text {eff }}$ and spared $\mathrm{T}_{\text {reg }}$ cells intact.

MSCs protect islet allografts from rejection To investigate the function of MSCs in mice that had received an islet transplantation, $1 \times 10^{6}$ splenocytes from $\mathrm{BALB} / \mathrm{c}$ mice alone (control) or together with $3 \times 10^{6} \mathrm{BALB} / \mathrm{c} \mathrm{MSCs}$ or BMFCs were intraperitoneally injected into diabetic (STZinduced) BALB/c $\mathrm{Rag}^{-/-} \gamma^{-1-}$ mice that had already had C57BL/6 islets transplanted under their renal capsules. Implantation of 500 islets resulted in an immediate establishment of normoglycaemia within 24-48 h post-transplant in all three groups (Fig. 4a). Blood glucose levels were typically maintained in the normal human range, between 5 and $7 \mathrm{mmol} / \mathrm{l}$.

Islet grafts were allowed to normalise for 2 days before the adoptive transfer of allogeneic splenocytes. As shown in Fig. 4a,b, acute rejection of the islet allografts was observed 
in all recipients, with a median graft survival time (MST) of 16 days after the adoptive transfer of an effector population (control, $n=5$ ). However, when the MSCs were co-transfered along with whole splenocytes, islet allograft survival was dramatically prolonged, with a MST of postoperative day (POD) $38(n=5,+$ MSC vs 16 POD in a control group, $p<$ 0.01 ; Fig. $4 \mathrm{~b}$ ). This effect was due solely to the survival of the transplanted islets and not to endogenous islet regeneration, as demonstrated by the fact that removal of the transplanted islets by nephrectomy in normoglycaemic recipients at day 38 resulted in an abrupt return to hyperglycaemia (Fig. 4a, arrow). Glucose homeostasis in BMFC co-transfer animals $(+\mathrm{BMFC})$ was comparable to that in the untreated control group $(n=4,+\mathrm{BMFC}$ vs control, $p>0.05$; Fig. $4 \mathrm{~b})$, and the animals became profoundly diabetic within 15-22 days (MST $=16.5$ days) as a result of unmodified allograft rejection. MSC-protected grafts, which showed as insulin-positive mass, were readily detected in the kidneys (+MSC; Fig. 4c) but were completely absent from mice administered BMFCs and from the control group.

These results demonstrate the beneficial effects of MSCs on graft survival in the mouse islet allograft model, although MSCs appeared to be unable to alter the tempo of rejection in the more stringently immunocompetent recipients: both MSC-treated and control mice promptly rejected grafts posttransplantation (C57BL/6 to BALB/c, data not shown). Furthermore, the protective activities of MSCs on the survival of islet grafts correlated with a substantial reduction in $\mathrm{T}$ cell infiltration into the islet grafts $(3.2 \%$ in the $+\mathrm{MSC}$ vs $11.4 \%$ in the control and $14.7 \%$ in + BMFC groups; Fig. $4 d$ ) and an induction of $\mathrm{CD}^{+} \mathrm{FOXP}^{+}{ }^{+} \mathrm{T}_{\text {reg }}$ cells $(17.6 \%$ in the $+\mathrm{MSC}$ group vs $9.2 \%$ in controls; Fig. 4 e).

MSCs suppress the proliferation of $T_{\text {eff }}$ cells in vivo To explore the mechanism underlying the action of MSCs in this model, $1 \times 10^{6} \mathrm{CFSE}-$ labelled splenocytes from BALB/c mice, alone or with $3 \times 10^{6}$ MSCs or BMFCs, were injected intraperitoneally into $\mathrm{BALB} / \mathrm{c} \mathrm{Rag}^{-/-} \gamma^{-/-}$mice that had previously been transplanted with islet allografts. Cells were recovered from the spleen, from the mesenteric lymph nodes and by peritoneal lavage of recipients at day 10 after adoptive transfer, and CFSE-labelled T cells were counted using flow cytometry. CFSE fluorescence is lost after cell proliferation, and maintenance of CFSE intensity is indicative of cells that have not undergone cycles of division. As shown in Fig. 5a, co-transfer of MSCs (+MSC) resulted in the profound suppression of $\mathrm{T}$ cell proliferation, with $2.0 \pm$ $0.3 \times 10^{4}$ CFSE-stained $\mathrm{CD}^{+} \mathrm{T}$ cells detected in the spleen, compared with $2.1 \pm 0.4 \times 10^{3}$ in the group co-transferred with BMFCs (+BMFC) and $2.3 \pm 0.7 \times 10^{3}$ in the control group (Fig. 5a, b). Analysis of absolute cell numbers also showed a marked suppression of $\mathrm{CD}^{+} \mathrm{T}$ cell proliferation in mesenteric lymph nodes and the peritoneal cavity a
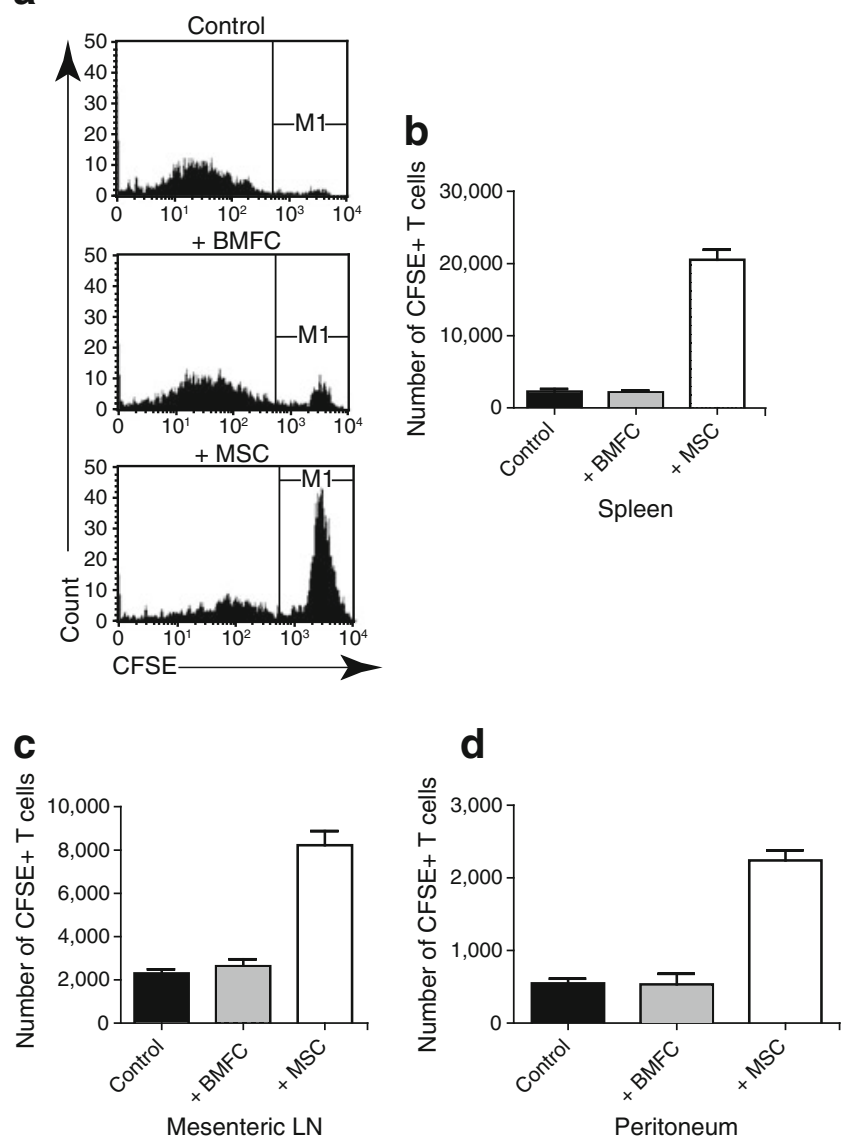

Fig. 5 MSCs suppress the proliferation and activation of $\mathrm{T}$ cells responding to alloantigens in vivo. Single-cell suspensions (BALB/c) were incubated for $10 \mathrm{~min}$ at $37^{\circ} \mathrm{C}$ with $10 \mu \mathrm{mol} / 1 \mathrm{CFSE}$, washed twice in ice-cold medium and resuspended in PBS for intraperitoneal injection. A total of $1 \times 10^{6} \mathrm{CFSE}-$ labelled splenocytes were injected intraperitoneally alone (control, $n=3$ ), or together with $3 \times 10^{6}$ autologous MSCs (+MSC, $n=3$ ) or BMFCs (+BMFC, $n=3$ ) into mice that had been previously engrafted with B6 islet allografts. Cells were recovered 10 days later from the spleen $(\mathbf{a}, \mathbf{b})$, mesenteric lymph nodes (LN) (c) and peritoneum (d). The quantification of the CFSE-labelled T cells in vivo was measured by FACS by gating for the $\mathrm{CD}^{+} \mathrm{CFSE}^{+}$population. Data are represented as mean $\pm \mathrm{SD}$

(Fig. 5c, d). These results suggested that $\mathrm{T}$ cell proliferation in response to islet allografting was attenuated by a cotransfer of MSCs, whereas in the group with a co-transfer of BMFCs and in the control group, there was no effect.

MSCs affect $T_{\text {eff }}$ cell differentiation in vivo and in vitro To determine the effect of MSCs on T cell differentiation in response to alloantigen stimulation, single-cell suspensions of spleens $(\mathrm{BALB} / \mathrm{c})$ were stimulated with irradiated C57BL/6 splenocytes for 5 days alone or in the presence of MSCs. Cells from co-cultures were then analysed for cytokine production by flow cytometry. As shown in Fig. 6a, the presence of MSCs led to a significant reduction in IFN- $\gamma$ production and increased IL-10 production in $\mathrm{T}$ 
Fig. 6 a $\mathrm{CD} 4^{+} \mathrm{CD} 25^{-} \mathrm{T}$ cells from the spleens of naive $\mathrm{BALB} / \mathrm{c}$ mice were prepared using a $\mathrm{CD} 4^{+} \mathrm{T}$ cell isolation kit. A total of $2 \times 10^{5}$

$\mathrm{CD} 4^{+} \mathrm{CD} 25^{-} \mathrm{T}$ cells (BALB/c) were co-cultured with $5 \times 10^{5}$ irradiated (3,600 rad) $\mathrm{C} 57 \mathrm{BL} / 6$ splenocytes in the presence of $1 \times 10^{4}$ MSCs for 5 days. The percentages of IFN- $\gamma-$, IL-10and IL-4-producing cells were evaluated by intracellular staining. Flow cytometric data are representative of three independent experiments. IFN- $\gamma(\mathbf{b})$, IL-10 (c), IL-4 (d) and TGF- $\beta$ (e) production by $\mathrm{CD} 4^{+}$splenocytes isolated from mice that had been transplanted with islet allograft under the kidney capsule before reconstitution with either $1 \times 10^{6} \mathrm{BALB} / \mathrm{c}$ splenocytes alone or together with $3 \times$ $10^{6}$ MSCs or BMFCs was analysed by FACS $(* * p<0.01$, $\mathrm{NS}=p>0.05 ; n=5$ for each group). Mice reconstituted with splenocytes alone or together with BMFCs were analysed at the time of rejection; mice reconstituted with splenocytes with MSCs were analysed at the end of the observation period

a
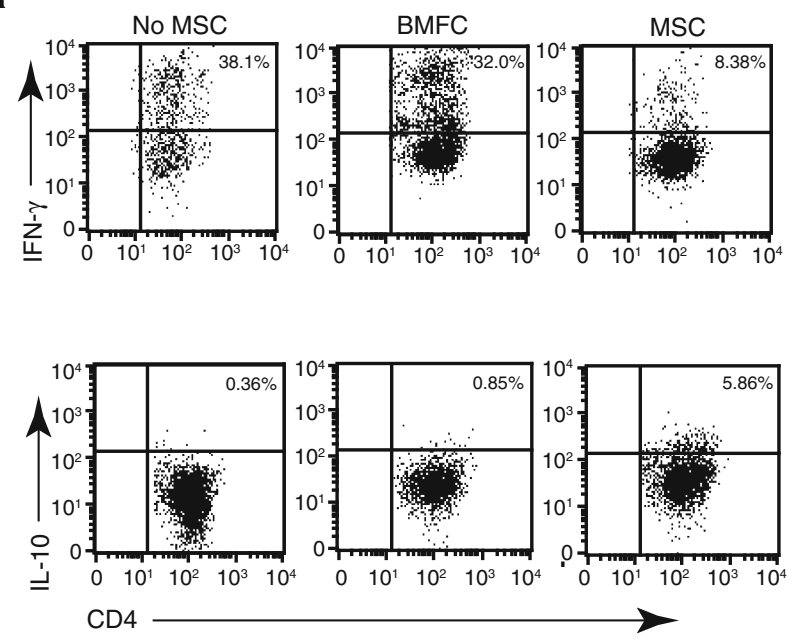

b

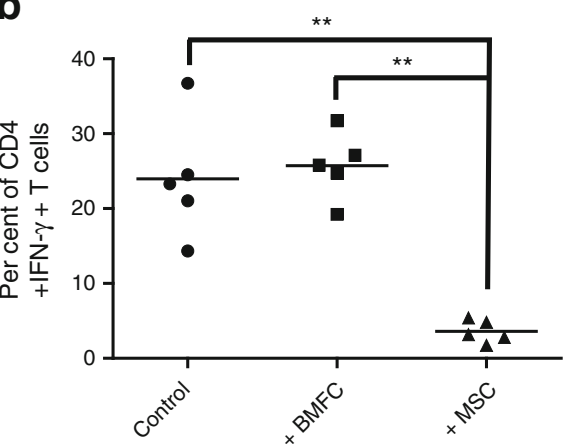

d

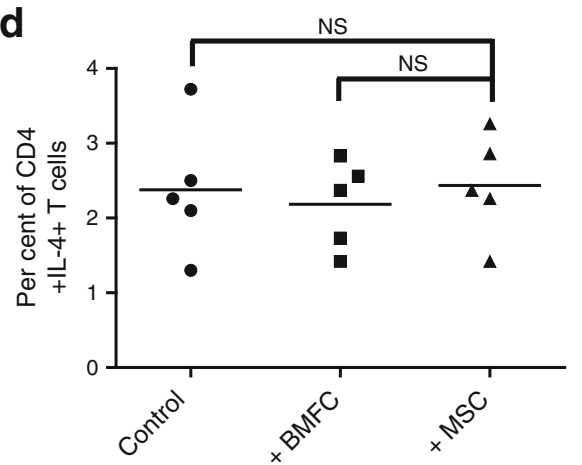

C
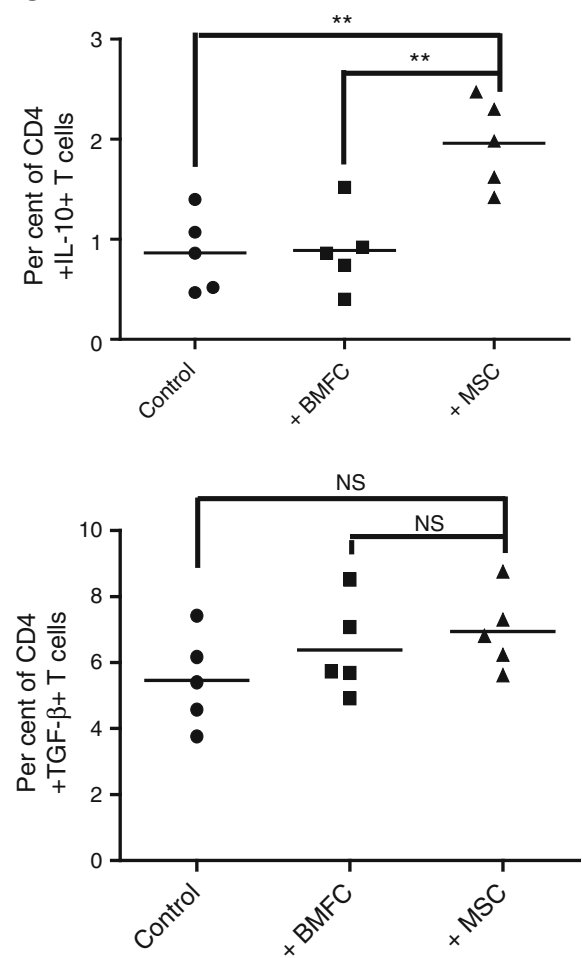

cells stimulated with alloantigens, whereas BMFCs had no effect.

We further investigated the development of $\mathrm{T}_{\text {eff }}$ cells in islet-transplanted recipients after the administration of MSCs or BMFCs, comparing these with the controls. At the time of rejection, or at the endpoint of the observation period, spleens from BALB/c $\operatorname{Rag}^{-1-} \gamma^{-/-}$mice adoptively transferred with splenocytes were harvested and analysed by flow cytometry. In parallel with the observations in vitro, MSC co-transfer dramatically prevented the production of IFN- $\gamma$ by $\mathrm{CD}^{+}{ }^{+} \mathrm{T}$ cells ( + MSCs vs control, $p<0.01$; Fig. 6b); meanwhile, treatment with BMFCs led to little change in IFN- $\gamma$ production ( + BMFCs vs control, NS [ $p>0.05]$; Fig. 6b). Conversely, IL-10 production was significantly elevated in the group given MSCs compared with the BMFC-treated and control groups ( $p<0.01$; Fig. 6c). MSC treatment, however, led to no effect on IL-4 and TGF- $\beta$ production, and the frequency of $\mathrm{CD} 4^{+} \mathrm{IL}-4^{+}$and $\mathrm{TGF}-\beta^{+}$ cells remained unchanged in comparison with the control group (+MSCs vs control; N.S $p>0.05$; Fig. 6d, e). Hence, our data demonstrate that MSCs were capable of modulating the allogeneic rejection response against islet allografts both in vitro and in an in vivo model of allogeneic islet transplantation. 
MSCs suppress alloreactivity by inducing $T_{\text {reg }}$ cells in vivo To address whether MSC administration induced the generation of $\mathrm{T}_{\text {reg }}$ cells, and thus contributed to the prolonged survival of islet allografts in vivo, mesenteric lymph nodes from recipients that had undergone an islet allograft were harvested at the time of graft rejection or the endpoint of the observation, and the absolute cell numbers of $\mathrm{CD} 4^{+} \mathrm{CD} 25^{+} \mathrm{FOXP}^{+}$cells were determined by flow cytometry. As shown in Fig. 7 a, elevated frequencies of $\mathrm{CD} 4^{+} \mathrm{CD} 25^{+} \mathrm{FOXP}^{+} \mathrm{T}_{\text {reg }}$ cells were observed in mice administered MSCs in comparison with the BMFC-treated or
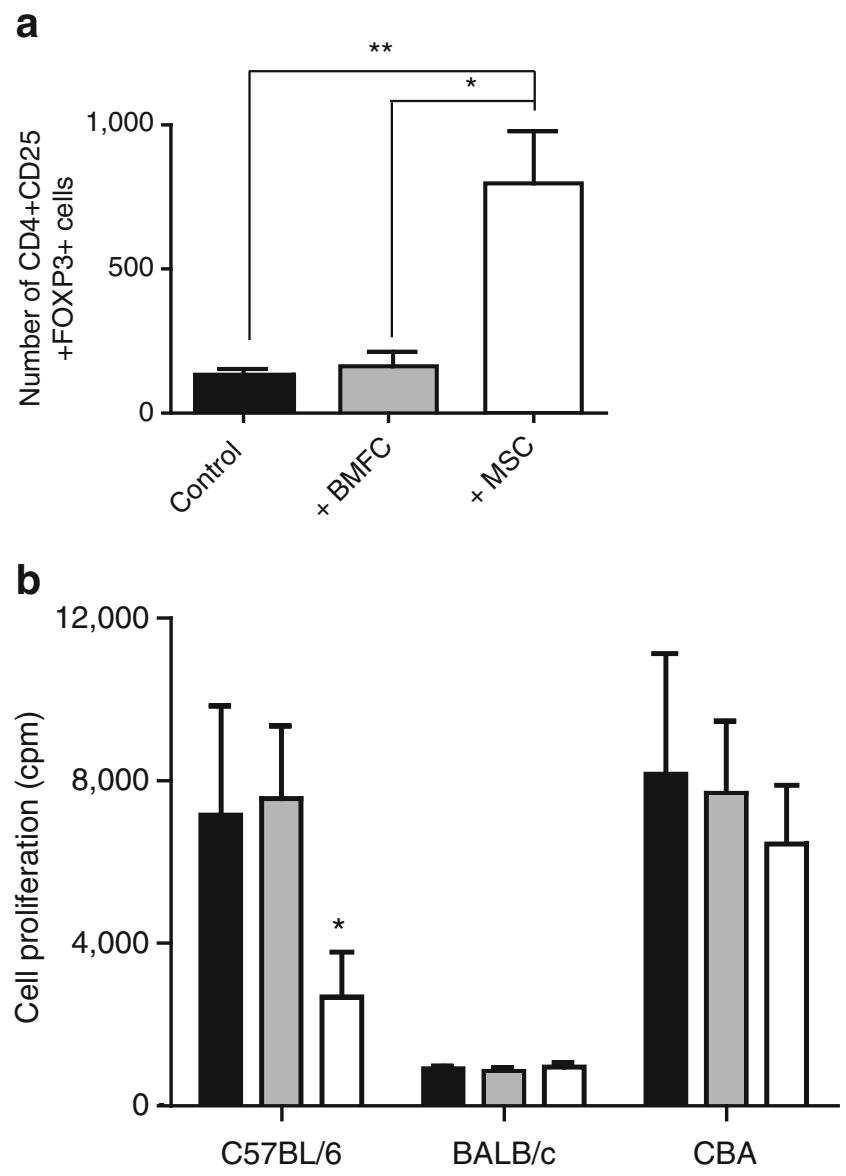

Fig. 7 a Mesenteric lymph nodes were harvested from islettransplanted recipients at the endpoint of observation. Absolute numbers of $\mathrm{CD} 4{ }^{+} \mathrm{CD} 25^{+} \mathrm{FOXP} 3^{+} \mathrm{T}$ cells were calculated by multiplying the percentages of the cell populations by the absolute number of beads added to the cells. Data from more than four animals per group are represented as mean $\pm \mathrm{SD}$. Student's $t$ tests were performed to evaluate the statistical difference. ${ }^{*} p<0.05,{ }^{*} p<0.01$. b Splenic cells from islet-transplanted recipients that were adoptively transferred with splenocytes only (black bars), or together with MSCs (white bars) or BMFCs (grey bars), were used as responder cells in the mixed lymphocyte reactions (MLR) $\left({ }^{*} p<0.05 ; n=4\right)$. A total of $2 \times 10^{5}$ responder cells were stimulated with $5 \times 10^{5}$ irradiated (3600 rad) splenocytes from naive $\mathrm{C} 57 \mathrm{BL} / 6$ donor, syngeneic $\mathrm{BALB} / \mathrm{c}$ mice or third-party CBA for $72 \mathrm{~h}$. Proliferation was assessed by ${ }^{3} \mathrm{H}-\mathrm{TdR}$ incorporation and was represented as counts per minute $(\mathrm{CPM}) \pm \mathrm{SD}$. Statistical comparisons were performed using one-way ANOVA control groups (+MSCs vs $+\mathrm{BMFC}, p<0.05$; + MSCs vs control, $p<0.01)$.

Next, we tested the immunological tolerance induced in the MSC-treated recipients in standard mixed lymphocyte reactions (MLR). Splenocytes from mice that had been treated with MSCs were harvested at the endpoint of observation, and those from mice treated with MSCs and mice in the control group were harvested when the islet allograft was rejected. Irradiated splenocytes from naive BALB/c, C57BL/6 and CBA mice served as antigen-presenting cells. The MLR assay revealed that splenocytes from recipients administered MSCs displayed a low level of cell proliferation in response to donor antigen-presenting cells compared with cells from the BMFC-treated group ( $p<0.05$; Fig. $7 \mathrm{~b}$ ), whereas the response to third-party CBA stimulation remained normal.

\section{Discussion}

To specifically modulate aberrant immune responses such as autoimmune disorders, allograft rejection or graft-vs-host disease by immunosuppressive therapy, while sparing $T_{\text {reg }}$ activity, it is crucial to obtain a more detailed insight into the biological differences between $\mathrm{T}_{\text {eff }}$ and $\mathrm{T}_{\text {reg }}$ cells. It is well recognised that MSCs can inhibit $\mathrm{T}$ cell responses induced by mitogens or alloantigens [4, 28]. Recently, it has been shown that regulatory lymphocytes are generated in cocultures of peripheral blood mononuclear cells with MSCs, which may potentiate the MSC-mediated immunosuppressive effect $[14,16]$.

Despite the far-reaching applications of MSCs in clinical situations, questions remain with regard to the mechanisms underlying the actions of MSC on $\mathrm{T}_{\text {eff }}$ and $\mathrm{T}_{\text {reg }}$ cells. In this paper, we characterised the impact of MSCs on the expansion and survival of $\mathrm{CD} 4^{+} \mathrm{CD} 25^{+} \mathrm{FOXP} 3^{+} \mathrm{T}_{\text {reg }}$ cells, as well as their proliferative response to IL-2, and found important differences compared with their $\mathrm{CD} 4^{+} \mathrm{CD} 25^{-} \mathrm{T}_{\text {eff }}$ counterparts. $\mathrm{T}_{\text {eff }}$ cells co-cultured with MSCs failed to respond to IL-2 stimulation and were more prone to apoptosis, in contrast to $\mathrm{T}_{\text {reg }}$ cells, which had a normal proliferative response to IL-2. The differential regulation of $T_{\text {eff }}$ and $T_{\text {reg }}$ cells by MSCs may provide novel insights into the development of successful immunotherapy in order to obtain a sufficient number of $\mathrm{T}_{\text {reg }}$ cells for clinical purposes, while reducing the risk of eliciting an unwanted alloreactive response in vivo.

The steadily growing interest in MSC-mediated immunosuppression has involved its potential in the activation, expansion and induction of $\mathrm{T}_{\text {reg }}$ cells from conventional $\mathrm{CD}^{+} \mathrm{T}_{\text {eff }}$ cells both in vivo and in vitro [29-31]. We previously demonstrated that matrix metalloproteinases -2 and -9 secreted by MSCs play an important role in MSC- 
mediated suppressive activity by reducing the surface expression of CD25 on activated $\mathrm{T}_{\text {eff }}$ cells [8]. Regulatory $\mathrm{CD}^{+} \mathrm{T}$ cells also constitutively express CD25. As an important $\mathrm{T}_{\text {reg }}$ marker, CD25 has been reported to be critical in the maintenance and expansion of $\mathrm{T}_{\text {reg }}$ populations $[26,32]$. It is also required for sustained expression of FOXP 3 and enhances the suppressive capacity of $\mathrm{T}_{\text {reg }}$ cells [33]. We therefore aimed to study the impact of MSCs on CD25 expression of $\mathrm{T}_{\text {reg }}$ cells and its functional importance on cell survival and proliferation.

Intriguingly, we found that MSCs differentially regulated CD25 expression on $\mathrm{T}_{\text {reg }}$ and $\mathrm{T}_{\text {eff }}$ cells. Despite being co-cultured with MSCs, CD25 expression on $\mathrm{T}_{\text {reg }}$ cells remained intact, in clear contrast to the reduced $\mathrm{CD} 25$ expression on $\mathrm{T}_{\text {eff }}$ cells. The differential regulation by MSCs of CD25 expression on different $\mathrm{T}$ cell compartments was functionally correlated with their survival and proliferative responses to IL-2. Taking all our results together, we have for the first time demonstrated that MSCs are capable of selectively fostering the survival and expansion of $T_{\text {reg }}$ cells, while inhibiting $\mathrm{T}_{\text {eff }}$ cells by inducing apoptosis and an impaired response to IL-2.

Emerging evidence has suggested that MSCs may offer therapeutic opportunities in islet transplantation by blunting the effector arm of the alloreactive response [3, 34]. Our findings that MSCs preferentially inhibit the expansion of $\mathrm{T}_{\text {eff }}$ cells while sparing $\mathrm{T}_{\text {reg }}$ activity prompted us to analyse the therapeutic potential of MSCs in an islet-transplanted mouse model. Recently, the therapeutic effects of MSCs in islet transplantation have been described in a non-primate animal model in which MSC treatment significantly enhanced islet engraftment and resulted in a reversal of rejection episodes [21].

In alignment with this study, we showed that coadministration of MSCs with allogeneic splenocytes led to a profound inhibition of the alloreactive response, a dramatic reduction in IFN- $\gamma$ and an augmented production of IL10 , and as a result favoured the induction of peripheral tolerance. Our results that treatment with MSCs resulted in an enhanced production of IL-10, with no effect on the level of TGF- $\beta$, suggest that IL-10 rather than TGF- $\beta$ could be involved in the functionality of these induced $\mathrm{T}_{\text {reg }}$ cells. Moreover, our results provide evidence that the immunosuppressive activity of MSCs occurs in a donor-specific manner since the alloresponse against a third unrelated party was largely intact. Nevertheless, it is unlikely that MSCs could be used as a stand-alone therapy in islet transplantation as the administration of MSCs apparently has no substantial therapeutic effect in immunocompetent murine recipients (data not shown). Further studies are warranted in order to optimise MSC-based therapy, especially its dosage and route, as well as possible combinations with accepted immunosuppressants.
Taken together, our results suggest that MSCs may hold the potential not only for the suppression of conventional $\mathrm{T}_{\text {eff }}$ cells, but also in the development of applications that could benefit transplantation through inducing the proliferation of $\mathrm{T}_{\text {reg }}$ cells. These findings cement the rationale for their implication in clinical islet transplantation.

Acknowledgements The authors are grateful to the staff at the Tongji Medical School Facilities for Animal Care and Housing for animal welfare. We thank DLV Bauer (Wellcome Trust Centre for Human Genetics, University of Oxford) for proofreading the manuscript.

Funding This work was supported in part by grants from the Research Foundation for Talented Scholars of the Huazhong University of Science and Technology and the National Natural Science Foundation of China (81101572).

Duality of interest The authors declare that there is no duality of interest associated with this manuscript.

Contribution statement DMX and YCD contributed to the conception and design of the research, conducting the experiments, data analysis and interpretation and manuscript writing, and gave final approval of manuscript. XFY, DZ, MXZ, JFZ and PHT contributed to analysis and interpretation of data, revised the draft critically for important intellectual content and gave approval of the final version to be published.

\section{References}

1. Prockop DJ (1997) Marrow stromal cells as stem cells for nonhematopoietic tissues. Science (New York) 276:71-74

2. Pittenger MF, Mackay AM, Beck SC et al (1999) Multilineage potential of adult human mesenchymal stem cells. Science (New York) 284:143-147

3. Ding Y, Bushell A, Wood KJ (2010) Mesenchymal stem-cell immunosuppressive capabilities: therapeutic implications in islet transplantation. Transplantation 89:270-273

4. Nauta AJ, Fibbe WE (2007) Immunomodulatory properties of mesenchymal stromal cells. Blood 110:3499-3506

5. Oh JY, Kim MK, Shin MS et al (2008) The anti-inflammatory and anti-angiogenic role of mesenchymal stem cells in corneal wound healing following chemical injury. Stem Cells 26:1047-1055

6. Rasmusson I, Ringden O, Sundberg B, Le Blanc K (2005) Mesenchymal stem cells inhibit lymphocyte proliferation by mitogens and alloantigens by different mechanisms. Exp Cell Res 305:3341

7. Glennie S, Soeiro I, Dyson PJ, Lam EW, Dazzi F (2005) Bone marrow mesenchymal stem cells induce division arrest anergy of activated T cells. Blood 105:2821-2827

8. Ding Y, Xu D, Feng G, Bushell A, Muschel RJ, Wood KJ (2009) Mesenchymal stem cells prevent the rejection of fully allogenic islet grafts by the immunosuppressive activity of matrix metalloproteinase2 and -9 . Diabetes 58:1797-1806

9. Bartholomew A, Sturgeon C, Siatskas M et al (2002) Mesenchymal stem cells suppress lymphocyte proliferation in vitro and prolong skin graft survival in vivo. Exp Hematol 30:42-48 
10. Chabannes D, Hill M, Merieau E et al (2007) A role for heme oxygenase-1 in the immunosuppressive effect of adult rat and human mesenchymal stem cells. Blood 110:3691-3694

11. Ge W, Jiang J, Baroja ML et al (2009) Infusion of mesenchymal stem cells and rapamycin synergize to attenuate alloimmune responses and promote cardiac allograft tolerance. Am J Transplant 9:1760-1772

12. Sakaguchi S (2005) Naturally arising Foxp3-expressing CD25 $+\mathrm{CD} 4+$ regulatory $\mathrm{T}$ cells in immunological tolerance to self and non-self. Nat Immunol 6:345-352

13. Sakaguchi S (2004) Naturally arising CD4+ regulatory T cells for immunologic self-tolerance and negative control of immune responses. Annu Rev Immunol 22:531-562

14. Prevosto C, Zancolli M, Canevali P, Zocchi MR, Poggi A (2007) Generation of CD4+ or CD8+ regulatory T cells upon mesenchymal stem cell-lymphocyte interaction. Haematologica 92:881-888

15. Carrion F, Nova E, Ruiz C, et al. (2010) Autologous mesenchymal stem cell treatment increased $\mathrm{T}$ regulatory cells with no effect on disease activity in two systemic lupus erythematosus patients. Lupus 19:317-322

16. Crop MJ, Baan CC, Korevaar SS, Ijzermans JN, Weimar W, Hoogduijn MJ (2010) Human adipose tissue-derived mesenchymal stem cells induce explosive T cell proliferation. Stem Cells and Development 19:1843-1853

17. Shapiro AM, Lakey JR, Ryan EA et al (2000) Islet transplantation in seven patients with type 1 diabetes mellitus using a glucocorticoidfree immunosuppressive regimen. N Engl J Med 343:230-238

18. Shapiro AM, Ricordi C, Hering BJ et al (2006) International trial of the Edmonton protocol for islet transplantation. N Engl J Med 355:1318-1330

19. Ryan EA, Lakey JR, Rajotte RV et al (2001) Clinical outcomes and insulin secretion after islet transplantation with the Edmonton protocol. Diabetes 50:710-719

20. Levitsky J, Gallon L, Miller J et al (2011) Allospecific regulatory effects of sirolimus and tacrolimus in the human mixed lymphocyte reaction. Transplantation 91:199-206

21. Berman DM, Willman MA, Han D et al (2010) Mesenchymal stem cells enhance allogeneic islet engraftment in nonhuman primates. Diabetes 59:2558-2568
22. Essery G, Feldmann M, Lamb JR (1988) Interleukin-2 can prevent and reverse antigen-induced unresponsiveness in cloned human $\mathrm{T}$ lymphocytes. Immunology 64:413-417

23. Le Blanc K, Rasmusson I, Gotherstrom C et al (2004) Mesenchymal stem cells inhibit the expression of CD25 (interleukin-2 receptor) and CD38 on phytohaemagglutinin-activated lymphocytes. Scand J Immunol 60:307-315

24. Groh ME, Maitra B, Szekely E, Koc ON (2005) Human mesenchymal stem cells require monocyte-mediated activation to suppress alloreactive T cells. Exp Hematol 33:928-934

25. Setoguchi R, Hori S, Takahashi T, Sakaguchi S (2005) Homeostatic maintenance of natural Foxp3(+) CD25(+) CD4(+) regulatory $\mathrm{T}$ cells by interleukin (IL)-2 and induction of autoimmune disease by IL-2 neutralization. J Exp Med 201:723-735

26. Sakaguchi S, Yamaguchi T, Nomura T, Ono M (2008) Regulatory T cells and immune tolerance. Cell 133:775-787

27. Maloy KJ, Powrie F (2005) Fueling regulation: IL-2 keeps CD4+ Treg cells fit. Nat Immunol 6:1071-1072

28. Di Nicola M, Carlo-Stella C, Magni M et al (2002) Human bone marrow stromal cells suppress T-lymphocyte proliferation induced by cellular or nonspecific mitogenic stimuli. Blood 99:3838-3843

29. Ghannam S, Pene J, Torcy-Moquet G, Jorgensen C, Yssel H (2010) Mesenchymal stem cells inhibit human Th17 cell differentiation and function and induce a $\mathrm{T}$ regulatory cell phenotype. $\mathrm{J}$ Immunol 185:302-312

30. Casiraghi F, Azzollini N, Cassis P et al (2008) Pretransplant infusion of mesenchymal stem cells prolongs the survival of a semiallogeneic heart transplant through the generation of regulatory T cells. J Immunol 181:3933-3946

31. Di Ianni M, del Papa B, de Ioanni M et al (2008) Mesenchymal cells recruit and regulate T regulatory cells. Exp Hematol 36:309-318

32. Rochman Y, Spolski R, Leonard WJ (2009) New insights into the regulation of $\mathrm{T}$ cells by gamma(c) family cytokines. Nat Rev 9:480-490

33. Fontenot JD, Rasmussen JP, Gavin MA, Rudensky AY (2005) A function for interleukin 2 in Foxp3-expressing regulatory $\mathrm{T}$ cells. Nat Immunol 6:1142-1151

34. English K, French A, Wood KJ (2010) Mesenchymal stromal cells: facilitators of successful transplantation? Cell Stem Cell 7:431-442 